\title{
COMMUNICATION SKILLS IMPROVEMENT WITH CROSS-CULTURAL ACTIVITIES IN A SUMMER CAMP
}

\section{Shevchenko Svitlana ${ }^{1}$}

DOI: https://doi.org/10.30525/978-9934-571-89-3_35

The communicative method defines the practical aim of teaching and learning languages, namely mastering cross-cultural communication through forming and developing cross-cultural competence and its components. When we speak about cross-cultural communication, we are concerning ourselves with the process of interpreting and sharing meanings with individuals from different countries.

Methodologist E.I. Passov in his conception of the development of a personality and individuality stresses that a foreign language should be taught cross-culturally. He places communication at the first place in teaching foreign languages and this particular communication is called cross-cultural or socio-cultural communication.

When we interact with the people of different cultures, we need to consider the role culture plays in making our communication understandable to each other. According to the cultural anthropologist Edward T. Hall, culture is communication and communication is culture [1, p. 126].

It should be mentioned that communication is a social process, in which the exchange of activities, experience, habits and skills is taking place. Under the cross-

\footnotetext{
${ }^{1}$ Tavria State Agrotechnological University, Ukraine 
cultural communication we understand the functionally determined communicative interaction of people who are the representatives of different cultures. The foreign partners differ from each other due to different outlook, views on life, habits, specific traditions and customs that are common for their particular countries. Lack of this knowledge causes difficulties in successful communication [1, p. 126].

Teaching communicative skills is a teaching technique as well as a professional behavior and a multilevel dynamic system of linguistic and methodological worth. It is necessary for a teacher to transform his knowledge into professional skills, that to be able to organize foreign languages communication via verbal and non verbal activities [2, p. 131].

Language activities and games like quiz, bingo, crossword, mingle, etc. are being incorporated into the language classes, providing opportunity to compensate for the missing knowledge, they involve matching and reordering, guessing and urging learners' memory, reading definitions of words and guessing the meanings, raise competitive powers of learning groups. On the part of the teacher it is important that they should organize such activities properly. It is necessary to activate the process of activity doing or playing, choose worthy materials, set time and find the proper place in classroom [2, p. 130].

The best place to combine learning English with pleasure and cross-cultural communication skills improvement is a summer camp. Nowadays there are a lot of summer camps with English learning programs in Ukraine. The great advantage of these programs is teaching English with native speakers or volunteers from different countries.

We can tell students about cultural differences using modern textbooks or internet resources. Students can find on the internet interesting or curious facts about foreign countries and use them in the classroom, but it is better to communicate with a real foreign representatives that to know true facts about cultural and everyday life of their countries. Furthermore, students should use only English. It is another great value and advantage of such communication. It is not so important to have crosscultural classes with native English speakers only. Representatives of any foreign country can realize the goals of such classes through English communication. The experience of my cross-cultural classes in the summer camp shows that Chinese, Indonesian, Tunisian, Turkish, Egyptian, Italian, Polish, Brazilian, Columbian, Estonian, Algerian, Slovenian, Swedish, Portuguese, Indian people can be fluent in English too. They tell real stories about their countries using photos, videos, drawings, national symbols and costumes. They cook national food and tell about history of their countries. Students ask questions they are interested in and tell about Ukraine. Mistakes and incorrect pronunciation do not stop communication. After every day classes and communication during three weeks the results are excellent. Goals of cross-cultural classes are achieved. Thus, students learn to understand cultural differences of different cultural groups, societies, behavioral patterns [3, p. 187-192]. 
It is advisable to use innovative techniques that are based on problem solving teaching that to arouse learners' interests and develop cross-cultural competence. The examples of such techniques are as follows:

1. Communicatively-searching tasks.

Read the text about cultural differences. Discuss the most amazing of them, compare with your country (e.g. Learners read the text about cultural differences in Indonesia and India, and then the volunteers from these countries add some more information about their countries. At this moment a discussion is taken place, children ask questions and compare information of the text with Ukraine);

Birthday party in different countries (Celebrating holidays and organizing parties is one of the most interesting topics for discussion. Foreign volunteers tell about step by step organization of parties in their countries, Ukrainian learners can compare, contrast and discuss given information).

2. Communicatively-oriented role plays.

Mingle activities include class questionnaires, matching activities (like "Finding your partner"), group dictations, and role plays.

The first class is good for the mingle role play activity "Find someone who...". All the learners are given the worksheet with the questions concerning some facts about personality, likes and dislikes of the people in the group. Everyone can try himself/ herself in the role of an interviewer and interviewee. Mingle activities are good for the learners of pre-intermediate and intermediate levels.

3. Cognitive-searching tasks.

Learning history of another country is very important for better understanding the culture of that country. One of the bright examples is "The day of Egypt". The volunteers from Egypt tell Ukrainian children about the gods and goddesses, main historical events and dates of their country. They tell about the meaning of ancient hieroglyphs or symbols of writing. During evening classes the learners have such activity as quest where all the notes are written with ancient hieroglyphs. The task is to decode the notes with help of English alphabet and find the presents. This activity is so exciting and perfect for communication skills improvement.

4. Cross-cultural communicative projects, reports, etc.

One of the favourite activities among Ukrainian children and adults in the camp is "Intercultural festival" when all the volunteers organize virtual short travelling around their countries. They make presentations about their countries, put on national costumes and tell about them; cook national dishes and treat with them; present national symbols, music and dance. This festival is the very activity for communication skills improvement and achieving cross-cultural goals.

Cross-cultural activities with foreign volunteers are great opportunity to learn about other cultures and lifestyles, form lifelong friendships, make lasting memories, and, of course, good opportunity to improve communication skills. Foreign language learners acquire cultural background in order to communicate and to increase their comprehension in the target language. 


\section{References:}

1. The Development of Socio-Cultural Competence at the Advanced Level. (2002). Ostroh. Conference Papers. (in English)

2. Formation of Skills for Communication and Teaching Word Games. (2002). Ostroh. Conference Papers. (in English)

3. Нові технології навчання: збірник наукових праць / ДНУ «Інститут модернізації змісту освіти». - К., 2018. - Вип. 91. - 272 с. 